\title{
The role of educational mobile apps in learning English (non-linguistic specialties)
}

\begin{abstract}
The article discusses approaches to effective use of mobile applications in the process of teaching a foreign language, their impact on improving the quality of students' knowledge, ways to effectively implement and test this aspect through non-traditional forms of education. The authors describe the practical significance of using educational mobile applications as a productive component that affects the content of the material, its systematization and assimilation. The relevance of the article is due to the rapid development of mobile applications for teaching foreign languages, the rapid development of the information society, which leads to the obsolescence of traditional technologies for teaching foreign languages, the need to correct them by using mobile applications in the educational process.
\end{abstract}

Keywords: modern information society, information technologies, mobile applications, foreign language, non-linguistic specialties.

As the modern information society develops, the demands placed on its participants become higher every year. These requirements relate not only to the high level of geopolitical economic requirements imposed on the modern employee, but also to the comprehensive training and development of the individual for participation in all spheres of social and political life. Thus, the need to learn a foreign language becomes a fashionable trend or additional educational baggage of the individual, but the objective reality and the introduction of innovative educational technologies for rapid and effective learning of a foreign language is the key to the needs of every citizen of the Republic of Kazakhstan.

Currently, our country is undergoing significant changes in the national educational policy. This is due to the transition to the position of personality-oriented pedagogy. One of the tasks of modern schools is to reveal the potential of all participants in the pedagogical process, providing them with opportunities to display their creative abilities. The solution of these problems is impossible without the implementation of the variability of educational processes, which is why there are various innovative types and types of educational institutions that require deep scientific and practical understanding [1].

Teaching foreign languages to students and schoolchildren with non-linguistic specialties faces an abundance of different problems. These problems are both technical and pedagogical in nature. Using mobile applications can speed up the process of learning communication skills and grammar patterns, but it will take time for both the student and the teacher to adapt at the initial stage.

The development and the promotion of modern society is influenced by information technologies, which plays a huge role in all areas of the world's population, ensuring the distribution and transmission of information around the world. Information technology is closely related to the field of linguistics. Previously, information technology was not required to improve the education of foreign languages, but now it is necessary for linguists and teachers to know this area.

In modern methods of teaching foreign languages, there are already a number of works related to mobile learning. S. V. Titova described the conditions for the successful implementation of mobile devices in the learning process and concluded that their application is relevant in the traditional course [2]. K.V. Kapranchikova studied the methodological potential of mobile applications such as email, dictionaries, blogs, etc. [3]. Y.V. Troshina and N. O. Verbitskaya reviewed models of mobile learning [4]. The methodological components of the selected applications - functions, types of tasks, types of content, motivational components, the presence of theory, hints and dictionary are described and studied in the article of M.Y.Ilushkina, A.M.Sheinkman, as well as their advantages and disadvantages are analyzed [5].

It is equally important to study using mobile information technologies (MIT) abroad. This problem was studied by such foreign researchers as K. Betti [6], V. M. Frank, S. Freinik, D. Richardson, and others [7].

The use of additional electronic learning systems, such as mobile applications, provides a solution to a number of problems related to the methodology of teaching a foreign language to students and schoolchildren of non-linguistic specialties. At the moment, there are approximately $1.5-1.6$ billion mobile devices, 
which in turn indicates the use of desktop computers is no longer so relevant and convenient for today's youth. Among the most popular educational applications in the field of learning foreign languages are: Lingualeo, Duolingo, Memrise, Easy Ten, Pussle English, Polyglot, etc.

Mobile devices are rapidly developing in technical terms: speed, reliability, and modernity. Almost everyone has them, even young children. This is a good tool for accessing information over the Internet, but not everyone uses this feature. The reason is that educational and cognitive motives are not in the first place, but rather entertainment.

Despite the fact that mobile devices have not yet found their niche for solving educational tasks, lessons using smartphones and tablets are quite common today.

Teaching English using interactive and mobile technologies provides high information content, visibility, intensity of learning and stimulation of activity.

Modern education requires the development of new approaches to teaching a foreign language. Thus, for more effective and exciting learning of English grammar, students of non-linguistic specialties have the opportunity to use specialized mobile applications for learning foreign languages that have recently become widespread in the classroom. They, among all other advantages, have the main thing in terms of the tasks we solve - the ability to automatically use modern teaching methods to develop the necessary communication skills and language (grammatical) patterns.

Moreover, the use of gadgets will greatly facilitate the activity of the teacher, since the app is able to automatically analyze the progress of the student's knowledge level, which in turn will save a lot of time for the teacher. Mobile apps also have the function of individually adapting algorithms for selecting topics for study and selecting those types of activity that are most suitable for the student.

Another important feature of specialized language mobile apps is their personalization. Since the mobile phone is an indispensable part of their daily life for today's youth, it is ideal as a channel for delivering various notifications and reminders for completing educational tasks. An interesting aspect of mobile applications is also the availability of various opportunities for additional motivation of students to perform the necessary educational tasks.

Applications can be used in various ways: both in English classes and for independent work of students; as mandatory components of the course, and additional use at will; as an auxiliary element of the topic or completely independent study of it, etc.

Titova S.V. in her article "Didactic problems of integration of mobile applications in the educational process" highlighted the following system of criteria for selecting high-quality applications: 1) availability in different systems (iOS, Android, Windows); 2) availability of an official website; 3) free installation of the application on a mobile device from a web store, the presence of paid elements is allowed (subscription, inapp purchases); 4) the ability to work at least partially offline (without using the Internet) or the ability to save the results for further study offline; 5) the interface in Russian; 6) the most popular (by the number of users) and with a rating of at least 4.5 [8].

One of the conditions for successful use of mobile applications in training is the readiness of participants in the educational process. As for students, it is necessary to have information about their technical equipment, competence and psychological readiness to use mobile applications when learning a language. To identify this, we asked some students to answer the questionnaire. The study was attended by 54 students of 1-3 courses of the faculty of philosophy and psychology, as well as the pedagogical faculty of the Karaganda State University named after E.A. Buketov.

According to the survey, all students have smartphones, and $14.8 \%$ of them also have tablet computers. In everyday life, students often use social networks, a browser, a camera, special computer programstranslators, e-mail, dictionaries, educational language applications, games. At the same time, $96.8 \%$ of students use mobile devices for study, including $88.7 \%$ for searching for information; $79 \%$ - for exchanging information via social networks and email, including with a teacher-38.7\%; $64.5 \%$ use electronic translators; $29 \%$ use dictionaries and $21 \%$ use educational applications.

The data obtained show that students have sufficient competence in the use of mobile devices and mobile applications. If we talk about the psychological readiness of students to implement learning mobile applications in language teaching, most of them have already tried to work independently with Lingualeo66.1\%; Duolingo-61.6\%; Puzzle English - 32.3\%; with Memrise - 21\%; Polyglot and BBC Learning English $-19.4 \%$; Bussu $-17.7 \%$ and other applications, $21 \%$ of students use such applications constantly.

Figure 1 shows the data obtained from a survey of students of 1-3 courses about the most frequently used educational mobile applications. 


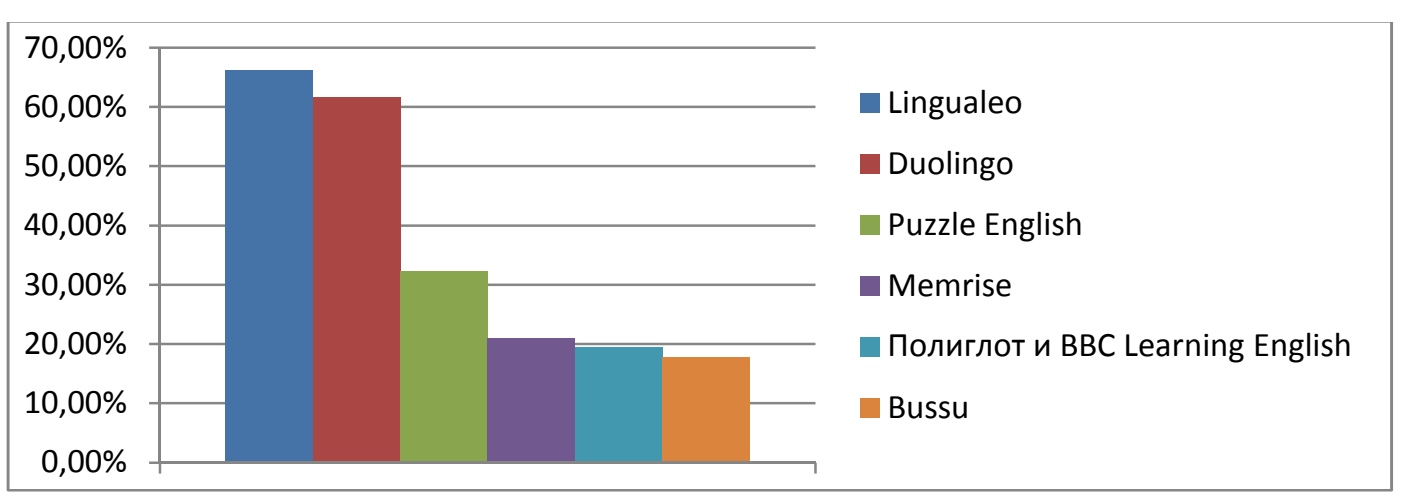

Figure 1. Most often used educational mobile applications by students

M.A. Odinokaya in her article "The role of educational mobile applications in learning English" paid special attention to the didactic characteristics of educational mobile applications and their capabilities [9]. This data is expressed in Table 1. Applications from this list are suitable for teaching students of nonlinguistic specialties with the level of knowledge of English Elementary and Pre-Intermediate.

$\mathrm{Tab}$ e 1

Educational apps designed for learning a foreign language

\begin{tabular}{|c|c|c|}
\hline Application name & System / OS & Functions \\
\hline $\bar{~} \overline{11}$ & $\overline{2}$ & $\overline{3}$ \\
\hline $\begin{array}{l}\text { Learn English } \\
\text { Elementary }\end{array}$ & iOS /Android & $\begin{array}{l}\text { It is a series of podcasts for students learning English, which can be } \\
\text { downloaded to mobile phones and engaged in any time convenient for } \\
\text { the user. Each issue lasts approximately } 20 \text { minutes and is accompanied } \\
\text { by questions for listeners. A «Ticker» is provided to facilitate } \\
\text { understanding. }\end{array}$ \\
\hline Duolingo & iOS/Android & $\begin{array}{l}\text { You can learn both English and Italian, French, Spanish, German, Por- } \\
\text { tuguese. It can be used as an additional guide with interactive exercises } \\
\text { for students learning Elementary level of English. An Internet connec- } \\
\text { tion is required to download the next stage of interactive classes. } \\
\text { The educational course is divided into stages according to the principle } \\
\text { «from simple to complex». The Duolingo educational application trains } \\
\text { such skills as writing and speaking (you will be asked to pronounce the } \\
\text { studied phrases), reading and listening. }\end{array}$ \\
\hline Memrise & iOS/Android & $\begin{array}{l}\text { You can learn both English and many other languages, it is a continua- } \\
\text { tion of the site of the same name. This application has an intuitive inter- } \\
\text { face, which in turn allows the user to immediately start learning foreign } \\
\text { language. Learning new words using images, practical interactive tasks } \\
\text { for repetition and fixing contribute to more effective vocabulary acqui- } \\
\text { sition. }\end{array}$ \\
\hline Grammar Up & iOS / Android & $\begin{array}{l}\text { It is intended for those students who periodically experience difficulties } \\
\text { in constructing foreign-language sentences, the use of articles and other } \\
\text { grammatical difficulties. The educational program contains the rules } \\
\text { and examples of usage. The student is given the opportunity to pass the } \\
\text { test, fixing and replenishing the lexical stock of words. Also, this app } \\
\text { has a version of Phrasal Verbs Lite, which allows you to practice con- } \\
\text { versational English using idioms and phrasal verbs. }\end{array}$ \\
\hline \begin{tabular}{|l} 
LinguaLeo \\
\end{tabular} & iOS / Android & $\begin{array}{l}\text { It offers four types of training: word-translation, translation-word, word } \\
\text { constructor, and listening. The app is integrated with a website that al- } \\
\text { lows you to study foreign words, read, listen to educational texts, and } \\
\text { solve crosswords. All words to be studied on the site become available } \\
\text { in the mobile version. }\end{array}$ \\
\hline
\end{tabular}




\begin{tabular}{|c|c|l|}
\hline \multicolumn{1}{|c|}{2} & \multicolumn{1}{|c|}{3} \\
\hline LangBook & iOS /Android & $\begin{array}{l}\text { It can be used for traditional translation, as well as for training. This ed- } \\
\text { ucational application offers users a thesaurus, explanatory, encyclope- } \\
\text { dic, geographical, engineering and many other dictionaries. In addition, } \\
\text { the app helps you learn a foreign language using interactive flashcards } \\
\text { with educational tasks that are well structured and divided by educa- } \\
\text { tional topics. The main purpose of the program is to perform the func- } \\
\text { tions of a dictionary. }\end{array}$ \\
\hline
\end{tabular}

Thus, the proposed approach to organizing foreign language training using mobile devices not only continues the previously established traditions of foreign language training using technical devices, but also expands them by using fundamentally new features of mobile platforms. It extends the language learning environment beyond the computer application and even the computer network. The experience gained in using the proposed mobile educational technologies has shown their feasibility and effectiveness in modern realworld educational practice. At the same time, the training of a foreign language, in particular, foreign language with the use of MIT, is implemented in the form of independent and playful activities, which in turn contributes to the successful development of English.

In conclusion, we can conclude that special language mobile applications allow you to speed up and improve the process of learning English. In addition, it is possible to personalize the process of learning English, develop stable language patterns, communication skills, learn grammatical rules and English. The use of such mobile applications in the study of English by students and students of non-linguistic specialties can significantly improve the quality of studying the subject. Learning English in groups using mobile applications makes it easier for the teacher to monitor students' achievements, which also provides conveniencefor the teacher's work.

\section{References}

1 Игембекова А.Ж. Эффективность использования инновационных технологий в обучении иностранному языку / А.Ж. Игембекова, Г.А. Ахметжанова, А.А. Горбачев // Вестн. Караганд. гос. ун-та. Сер. Педагогика. — 2017. — № 4(88). C. 24-27.

2 Титова С.В. Условия успешной интеграции мобильных устройств в учебный процесс / С.В. Титова // Современные информационные технологии и ИТ-образование. — 2012. — № 8. - С. 262-269.

3 Капранчикова К.В. Мобильные технологии в обучении иностранному языку студентов нелингвистических направлений подготовки / К.В. Капранчикова // Язык и культура. — 2014. — № 1 (25). — С. 84-94.

4 Трошина Ю.В. Мобильное обучение иностранному языку: понятие, функции, модели [Электронный ресурс] / Ю.В. Трошина, Н.О. Вербицкая // Современные проблемы науки и образования. — 2015. — № 3. — Режим доступа: http://bit.ly/2KIXxdi

5 Илюшкина М.Ю. E-learning в преподавании английского языка: анализ контента мобильных приложений [Электронный ресурс] / М.Ю. Илюшкина, А.М. Шейнкман // StudiaHumanitatis. — 2019. — № 2. - Режим доступа: http://www.sthum.ru/

6 Beatty K. Mobile language learning: the world in our hands [Electronic resource] / K. Beatty // Anaheim University, USA. 2015 - № 17. - Access mode: https://www.anaheim.edu/schools-and-institutes/graduate-school-of-education/diploma-intesol/243-\%20about/faculty-and-staff/tesol-faculty/886-ken-beatty-phd-ken-beatty-phd

7 Frank V.M. Technologies for foreign language learning: a review of technology types and their effectiveness [Electronic resource] / V.M. Frank, S. Freynik, D.L. Richardson // Center for Advanced Study of Language, University of Maryland, College Park, MD. - 2014. - Vol. 27, No. 1. - Access mode: https://www.learntechlib.org/p/153571

8 Титова С.В. Дидактические проблемы интеграции мобильных приложений в учебный процесс / С.В. Титова // Вестн. Тамбов. ун-та. - 2016. - С. 7-14.

9 Одинокая М.А. Роль образовательных мобильных приложений в изучении английского языка [Электронный ресурс] / М.А. Одинокая, М.В. Коллерова // Центр научного сотрудничества «Интерактив плюс». — 2017. — № 12. — Режим доступа: https://interactive-plus.ru/ru 


\title{
Д.Н. Асанова, А.Б. Прлепесова \\ Ағылшын тілін оқытудағы білім беру мобильді қосымшаларының рөлі (лингвистикалық емес мамандықтар)
}

\begin{abstract}
Мақалада шетел тілін оқыту процесінде мобильді қосымшаларды тиімді пайдалану тәсілдері, олардың студенттердің білім сапасын арттыруға әсері, оқытудың дәстүрлі емес түрлері арқылы осы аспектіні тиімді енгізу және апробациялау жолдары қарастырылған. Авторлар білім беру мобильді қосымшаларын материалдың мазмұнына, оны жүйелеуге, меңгеруге әсер ететін өнімді компонент ретінде қолданудың практикалық маңыздылығын сипаттайды. Мақала тақырыбының өзектілігі шет тілдерін оқытуға арналған мобильді қосымшалардың жылдам дамуымен, ақпараттық қоғамның қарқынды дамуымен байланысты, бұл шет тілдерін оқытудың дәстүрлі технологияларының ескіруіне, білім беру процесінде мобильді қосымшаларды пайдалану арқылы оларды түзету қажеттігіне алып келеді.
\end{abstract}

Кілт сөздер: қазіргі ақпараттық қоғам, ақпараттық технологиялар, мобильді қосымшалар, шетел тілі, лингвистикалық емес мамандықтар.

\section{Д.Н. Асанова, А.Б. Прлепесова \\ Роль образовательных мобильных приложений в изучении английского языка (нелингвистические специальности)}

\begin{abstract}
В статье рассмотрены подходы эффективного использования мобильных приложений в процессе обучения иностранному языку, их влияние на повышение качества знаний студентов, пути эффективного внедрения и апробации данного аспекта через нетрадиционные формы обучения. Авторами описана практическую значимость использования образовательных мобильных приложенний как продуктивной составляющей, влияющей на содержание материала, его систематизацию и усвоение. Актуальность темы статьи обусловлена быстрым развитием мобильных приложений для обучения иностранным языкам, стремительным развитием информационного общества, что приводит к устареванию традиционных технологий преподавания иностранных языков, потребностью их корректирования путем использования мобильных приложений в образовательном процессе.
\end{abstract}

Ключевые слова: современное информационное общество, информационные технологии, мобильные приложения, иностранный язык, нелингвистические специальности.

\section{References}

1 Igembekova, A.Zh., Akhmetzhanova, G.A.,. \& Gorbachev, A.A. (2017). Effektivnost ispolzovaniia innovatsionnykh tekhnolohii v obuchenii inostrannomu yazyku [Efficiency of using innovative technologies in foreign language education]. Vestnik Karahandinskoho universiteta. Seriia Pedahohika, No. 4(88), 24-27 [in Russian].

2 Titova, S.V. (2012). Usloviia uspeshnoi intehratsii mobilnykh ustroistv v uchebnyi protsess [Conditions for successful integration of mobile devices into the learning process]. Sovremennye informatsionnye tekhnolohii i IT-obrazovanie, No. 8, 262-269 [in Russian].

3 Kapranchikova, K.V. (2014). Mobilnyye tekhnolohii v obuchenii inostrannomu yazyku studentov nelinhvisticheskikh napravlenii podhotovki [Mobile Technologies in Foreign Language Education for Non-Linguistic Students]. Yazyk $i$ kultura, No. 1 (25), 84-94 [in Russian].

4 Troshina, Yu.V., \& Verbitskaya, N.O. (2015). Mobilnoe obuchenie inostrannomu yazyku: poniatie, funktsii, modeli [Mobile foreign language training: concept, functions, models]. Sovremennye problemy nauki $i$ obrazovania, No. 3 . Retrieved from http://bit.ly/2KIXxdi [in Russian].

5 Ilyushkina, M.Yu., \& Sheynkman, A.M. (2019). E-learninh v prepodavanii anhliiskoho yazyka: analiz kontenta mobilnykh prilozhenii [E-learning in teaching English: analyzing mobile app content]. Studia Humanitatis, No. 2. Retrieved from www.sthum.ru [in Russian].

6 Beatty, K. (2015). Mobile language learning: the world in our hands. Anaheim University, USA, No. 17. anaheim.edu. Retrieved from www.anaheim.edu/schools-and-institutes/graduate-school-of-education/diploma-in-tesol/243- about/faculty-andstaff/tesol-faculty/886-ken-beatty-phd-ken-beatty-phd

7 Frank, V.M., Freynik, S., \& Richardson, D.L. (2014). Technologies for foreign language learning: a review of technology types and their effectiveness. Center for Advanced Study of Language, University of Maryland, College Park, MD, No. 1, 27. Retrieved from https://www.learntechlib.org/p/15357

8 Titova, S.V. (2016). Didakticheskiie problemy intehratsii mobilnykh prilozhenii v uchebnyi protsess [Didactic Issues Integrating Mobile Applications into Learning]. Vestnik Tambovskoho universiteta - Bulletin of the Tambov University, 7-14 [in Russian].

9 Odinokaya,M.A., \& Kollerova, M.V. (2017). Rol obrazovatelnykh mobilnykh prilozhenii v izuchenii anhliiskoho yazyka [Role of educational mobile applications in learning English]. Scientific Cooperation Center «Interactive plus», No. 12. https://interactive-plus.ru/ru [in Russian]. 